\title{
Wage Convergence and Trade
}

\author{
by Yixiao Zhou and Harry Bloch*
}

School of Economics and Finance, Curtin University

\begin{abstract}
$\underline{\text { Abstract }}$
We examine differences in wage rates across countries for workers working in the same industry, distinguishing workers in the low- medium- and high-skill groups. These differences are large and show persistence over time. We ask, nonetheless, whether there is evidence of unconditional or conditional convergence, much as is done in studies of convergence in per-capita income across countries. With our focus on the micro level we expect convergence to reflect, at least in part, the degree of integration of an industry into the world economy and examine particularly the role of exposure to trade in goods and services.
\end{abstract}

Our results show strong evidence of convergence in a diverse sample of 40 countries, which includes most large economies whether rich or poor. The estimated unconditional convergence rate over the period from 1995 to 2008 is about 2\% per year for workers in all skill groups, though rising with exposure to imports and falling with export intensity. When we control for variation in the rate of growth of domestic production as well as for direct effects of trade exposure, we find the estimate of resulting conditional rate of convergence is not much different from the unconditional estimates even though each of the control variables impact significantly on the growth of wages relative to the convergence prediction for at least some skill level.

Corresponding author: Harry Bloch: $\underline{\text { h.bloch@curtin.edu.au }}$

Yixiao Zhou: Yixiao.Zhou@curtin.edu.au 
Wage Convergence and Trade

\section{Introduction}

In spite of globalisation wage rates for similar tasks undertaken in the production of similar goods often vary substantially across countries. Even where most barriers to trade and movement of people and investment are removed, as in the European Union, wage differentials persist. In this paper, we consider whether the persistence of wage differentials is due, at least in part, to the time it takes for domestic wages to adjust to external forces, particularly when trade connections are limited. We also allow for wage rates to be influenced directly by trade exposure and by purely domestic disturbances, leading to deviations from the underlying path of convergence.

A primary focus of empirical research on the relationship between trade and wages has been on how trade affects wage levels and differentials within a country (see Haskel, et al. (2012) for a review of the literature). Our focus is somewhat different. We examine the tendency for convergence over time in wage rates across a wide range of countries for the same type of labour. For the greatest equivalence possible with available data, we examine convergence in the wage differential across countries for workers of a particular skill level working in the same industry classification. The questions we seek to answer are whether wage differentials are indeed decreasing over time and whether the rate of change in the differential is related to exposure to trade as measured by the ratio of exports or imports to domestic production. We also examine the impact of trade exposure and domestic disturbances as a source of deviations from convergence.

With the factor-price-equalisation (FPE) theorem of Samuelson and Stolper (1941), free trade in finished goods leads to equal relative compensation across trading partners for any productive input, albeit under a set of highly restrictive assumptions. Subsequent theorising has maintained the focus on the market integrating impact of trade but without relying on the Samuelson-Stolper framework. For example, a recent contribution by Baldwin and Robert-Nicoud (2014) demonstrates the impact on wage convergence under outsourcing (trade-in-tasks) rather than trade-in-goods.

Theoretical analysis of the integrating impact of trade has generally involved comparison of equilibrium positions, with equilibrium before any trade between countries (autarky) compared to equilibrium after full adjustment of domestic production and consumption to whatever trade opportunities are available. Adjustment to equilibrium takes time. Moving from autarky to trade equilibrium involves shifting production in each trading partner to products in which they have an advantage based on factor endowments, scale economies or other influences. This can't be done quickly without incurring great costs, especially when long-lived capital equipment and job-specific skills are involved. Each country may also have institutional and legal impediments to shifting inputs across industries or adjusting product and input prices, especially wage rates.

Globalisation has involved learning of the opportunities for profitable trade and then developing the connections to exploit these opportunities. Such learning can be a slow process, particularly if there are language and cultural differences between potential trading partners. Further, the modern institutions that facilitate trade, such as the World Trade Organization and freetrade agreements, are works in progress with continuing adjustment over time and they operate in conjunction with national institutions that have independent influence. Thus, Ramskogler (2012) finds evidence that Germany is a wage leader within the European Monetary Union, which supports the peer-wage setting hypothesis of Traxler, et al. (2008).

Even within the integrated market of the European Union (EU), Parteka and WolszczakDerlacz (2014) find substantial variation across $27 \mathrm{EU}$ member states in 2009 for the exchange-rate adjusted wage rate of workers of the same skill level and industry of employment. The range of the 
average wage rate differential for low-skill workers between the best paid (Belgium) and worst paid (Bulgaria) is close to twenty to one and the range for medium-skill and high-skill workers is not much smaller. While the lowest relative wages are in countries that have most recently joined the EU, wage rate ranges of two to one are not uncommon across early EU member states. For the core group of eleven EU countries Mora at al. (2005) find evidence of convergence in national average wages at a rate of slightly less than $2 \%$ per annum over the period 1981 to 2001 . Clearly, wage equalisation is not a quick process.

We examine convergence of wage rates for a sample of 40 diverse countries, including all the G7 countries and most large late-industrialising countries (for example, Brazil, Russia, India, China and Indonesia). We compare wage rates for each of three skill groups (low, medium and high) within each of 27 industry classifications, spanning manufacturing, primary and service sectors. Wage rates over the sample vary more widely than in the EU, with a range of over 100 to one for each skill group. Our objective is to determine whether the large disparities in wages rates show a tendency to converge and, if so, whether the rate of convergence is impacted by exposure to exports and imports.

In the next section, we model the adjustment process affecting relative wage rates. We allow for the possibility that the rate of adjustment depends on exposure to trade in goods. We also allow relative wages to be affected directly by trade exposure and by domestic conditions as measured by output growth, which leads to deviations from the convergence path. The following section explains the data we use in studying wage convergence and presents summary measures across all industries to show the degree of variation in wage rates for workers of low skill, medium skill and high skill across the 40 countries in our sample.

Results from our regression analysis of the changes in relative wage rate are presented in the penultimate section and show strong evidence of convergence across countries in wage rates for workers in all skill groups. We estimate convergence occurs at a rate of about $2 \%$ a year for workers of each skill group (comparable to the findings of Mora, et al., 2005, cited above), with the rate substantially higher when import intensity is high and substantially lower when export intensity is high. Also, relative wage rates are positively related to the contemporaneous rate of growth in industry output in the country, which implies that differences in output growth rates across countries lead to deviations from the convergence path for the industry. Exposure to trade also leads to deviations from the convergence path, with relative wage rates for low- and medium-skill workers rising with exposure to imports and relative wage rates for high-skill workers rising with exposure to exports. A final section of the paper summarises our results and provides commentary on the implications of our results for understanding the process of wage convergence and the role of goods trade in this process.

\section{Trade and adjustment towards wage equalisation}

International trade links markets across countries by providing opportunities for arbitrage. In the extreme case, prices of traded goods are equalised across countries in terms of a common currency. Domestic producers in each country adjust their choices of inputs and outputs to these prices in the pursuit of maximum profits. This impacts on the demand for inputs to production and in the limit yields an identical price expressed in common currency across all countries according to the factor price equalisation (FPE) theorem of Samuelson and Stolper (1941). Through trade in finished goods, all markets across the world become part of an integrated production system.

In practice there is a spectrum of connections between markets, ranging from total isolation to complete integration. When markets are completely integrated, arbitrage works to equalise the 
prices of identical commodities and inputs to production. When markets are totally isolated, conditions particular to each market determine prices and differentials are expected in the price of the same item across markets. Trade in finished goods serves to enhance the connection between national markets as do movements of inputs (immigration and foreign investment). Recently, outsourcing (trade-in-tasks) has been shown to also to have integrating impact and to lead to effects on input prices related to the FPE effects (Baldwin and Robert-Nicoud, 2014).

The theoretical analysis of international integration focuses on comparison of equilibrium positions before and after some change in conditions, such as a movement from autarky to free trade in goods. In practice, the process of globalisation has involved enhanced linkages among national markets over a long period of time. This process has been driven in part by technological change, with improvements in transportation and communication opening possibilities for cheaper and speedier movement of goods and services as well as people and finance across national borders (O'Rourke and Williamson, 1999). There has also been a general, although uneven, movement towards the lessening of policy-imposed barriers to this movement, especially in the period after the Second World War. Organisational change has further enhanced linkages in both the private sector, with the growth of multinational firms and global supply chains, and the public sector, with international trading rules and agreements administered by agencies such as the World Trade Organisation.

Arbitrage is reasonably quick in well integrated markets like an organised securities exchange, but otherwise takes time. The enhancement in international linkages in markets has occurred slowly and not always smoothly, over time. Thus, the effects of linking markets on wages is best understood as a process taking place gradually over time, whilst allowing for interruptions due to policy changes and other factors that disturb the international flow of goods, tasks, people and finance.

We model wage convergence as a process occurring gradually in time with an initial position of autarkic markets and an eventual destination of a long-run equilibrium degree of market integration and equalisation of wages for each particular type of labour. The domestic wage of the $i^{\text {th }}$ worker type is given by $w_{i}$, while the wage of a corresponding foreign worker is given by $w_{i}^{*}$. A smooth exponential process of adjustment in the relative wage of the $i^{\text {th }}$ worker type is represented by

$\left(w_{i} / w_{i}^{*}\right)_{t}=\left(w_{i} / w_{i}^{*}\right)_{0}^{\theta^{t}}\left(w_{i} / w_{i}^{*}\right)_{\infty}{ }^{1-\theta^{t}}, 1>\theta>0$

where $\left(w_{i} / w_{i}^{*}\right)_{0}$ is the relative wage in the initial position of autarky, $\left(w_{i} / w_{i}^{*}\right)_{\infty}$ is the value of the wage ratio with whatever degree of equalisation occurs at the infinite horizon and $\theta$ is a measure of the degree of persistence in relative wages. ${ }^{1}$

In Equation (1) $t$ is the number of time periods from first exposure of the domestic market to the influence of foreign markets. When the domestic market operates initially without exposure to foreign markets, $t=0$ and $\theta^{t}$ equals 1 so that only autarkic relative wages influence current relative wages. As $t$ grows towards infinity, $\theta^{t}$ becomes increasingly small and current relative wages depend almost completely on the relative wages with full integration. While measuring the number of periods since exposure of a domestic market to the influence of foreign markets may seem problematic, it turns out to be unnecessary when examining the adjustment of relative wages over a sub-period of time.

\footnotetext{
${ }^{1}$ In the limiting case of full equalisation $\left(w_{i} / w_{i}^{*}\right)_{\infty}$ takes the value of 1.0, which when raised to any power is still 1.0, and the expression in Equation (1) simplifies to $\left(w_{i} / w_{i}^{*}\right)_{t}=\left(w_{i} / w_{i}^{*}\right)_{0} \theta^{t}$.
} 
Taking logarithms of both sides of (1) yields

$\ln \left(w_{i} / w_{i}^{*}\right)_{t}=\left(1-\theta^{t}\right) \ln \left(w_{i} / w_{i}^{*}\right)_{\infty}+\theta^{t} \ln \left(w_{i} / w_{i}^{*}\right)_{0}$

The adjustment over time in the relative wage is given by taking the first difference of (2) to yield

$$
\ln \left(w_{i} / w_{i}^{*}\right)_{t}-\ln \left(w_{i} / w_{i}^{*}\right)_{t-1}=\left(\theta^{t-1}-\theta^{t}\right)\left(\ln \left(w_{i} / w_{i}^{*}\right)_{\infty}-\ln \left(w_{i} / w_{i}^{*}\right)_{0}\right)
$$

which simplifies to an expression in current and lagged relative wages as follows:

$$
\begin{aligned}
\ln \left(w_{i} / w_{i}^{*}\right)_{t}-\ln \left(w_{i} / w_{i}^{*}\right)_{t-1}= & (1-\theta) \theta^{t-1}\left(\ln \left(w_{i} / w_{i}^{*}\right)_{\infty}-\ln \left(w_{i} / w_{i}^{*}\right)_{0}\right) \\
& =-(1-\theta)\left[\ln \left(w_{i} / w_{i}^{*}\right)_{t-1}-\ln \left(w_{i} / w_{i}^{*}\right)_{\infty}\right]
\end{aligned}
$$

In the limiting case of full wage equalisation $\left(w_{i} / w_{i}^{*}\right)_{\infty}$ takes the value of 1.0, which means the last term in Equation (4) takes a value of zero and the expression simplifies to

$\ln \left(w_{i} / w_{i}^{*}\right)_{t}-\ln \left(w_{i} / w_{i}^{*}\right)_{t-1}=-(1-\theta) \ln \left(w_{i} / w_{i}^{*}\right)_{t-1}$

This form of the equation is particularly attractive for estimation purposes as the value of relative wages under less than complete integration of markets is unobservable. Thus, we use the relationship in Equation (5) for our basic estimating equation in our empirical results below and then check for possible misspecification through robustness tests.

The expression for the log difference in relative wages from Equation (5) provides the basis for specifying of the estimation equation for wage convergence. The observed value of the logarithm of relative wage in period $t$ is denoted by $\omega_{t}$, where

$\omega_{t}=\ln \left(w_{i} / w_{i}^{*}\right)_{t}+\mu_{t}$

The disturbance term, $\mu_{t}$, captures the impact of factors that lead to deviations of the relative wage from the path of smooth adjustment. Substituting from Equation (6) into Equation (5) yields

$\Delta \omega_{t}=-(1-\theta) \omega_{t-1}+\mu_{t}-\theta \mu_{t-1}$

The negative of the coefficient of the lagged relative wage rate in Equation (7) provides a measure of the rate of convergence over the interval between period $t-1$ and period $t$, which can be expressed as an annual rate approximately equal to $(1-\theta)$ divided by $t$ minus $t-1$ years. ${ }^{2}$ We are interested in examining whether exposure to trade has an impact on this speed. For this purpose, we allow for a linear relationship between trade intensity and the speed of convergence as follows:

$-(1-\theta)=b_{0}+b_{1} m+b_{2} x$

where $m$ is the ratio of imports to domestic sales (domestic production plus imports) and $x$ is the ratio of exports to domestic production, while the $b_{i}$ are estimated coefficients. If exports and imports are both nil, then the estimate of $-b_{0}$ provides an estimate of the amount of convergence,

\footnotetext{
${ }^{2}$ The approximation is better the smaller is the value of $(1-\theta)$ and the lower is the number of years in the interval over which convergence is estimated.
} 
which is less than zero if there is convergence occurring even in the absence of trade (say due to immigration, capital flows or technology transfer). The estimated speed of convergence increases (decreases) with exposure to imports if the estimate of $b_{1}$ is negative (positive) and similarly for $b_{2}$ with exports. Combining Equations (7) and (8) yields our estimating equation for unconditional wage convergence,

$\Delta \omega_{t}=\left(-b_{0}+b_{1} m+b_{2} x\right) \omega_{t-1}+\mu_{t}-\theta \mu_{t-1}$

As well as interacting with the lagged wage rate, exports and imports may exert a direct impact on changes in the wage rate through being factors that contribute to deviations in the smooth adjustment path, which is reflected in the $\mu_{t}$ variable in Equation (6). ${ }^{3}$ Another potential disturbing factor is changes in the derived demand for labour arising from changes in domestic production. We allow for exposure to trade and domestic production growth impacting on the current disturbance term as follows:

$\mu_{t}=\gamma_{0}+\gamma_{1} \Delta q_{t}+\gamma_{2} m+\gamma_{3} x+\varepsilon_{t}$

where $\Delta q_{t}$ is the first difference of the logarithm of domestic production between period $t-1$ and period $t$ and $\varepsilon_{t}$ is included to allow for other disturbances that affect current relative wage rates. Substituting from Equation (10) into Equation (9) and excluding the term $\theta \mu_{t-1}$ gives the relationship used as the basis for the following estimating equation in the regression analysis of our study: ${ }^{4}$

$\Delta \omega_{t}=\gamma_{0}+\left(b_{0}+b_{1} m+b_{2} x\right) \omega_{t-1}+\gamma_{1} \Delta q_{t}+\gamma_{2} m+\gamma_{3} x+\varepsilon_{t}$

In addition to this full regression, we estimate reduced regressions. First, we eliminate the variables that impact wage change through the disturbance terms in Equation (7), which are the output growth variable, $\Delta q_{t}$, and the separate import and export intensity variables, $m$ and $x$. Estimates from this reduced regression are unconditional in the sense that they are no longer conditional on controlling for factors that disturb the convergence path for wage rates. Second, we eliminate the import and export intensity variables to estimate a constant rate of unconditional convergence across industries. The full set of regression results provides parallel treatment to the approach taken in the literature on convergence in per capita income across countries. ${ }^{5}$

\section{Data and estimation}

The World Input-Output Database (WIOD) contains annual time-series of world input-output tables and factor requirements covering the period from 1995 to 2008 for two-digit NACE industries in

\footnotetext{
${ }^{3}$ Exposure to trade may impact on wage movements independent of an influence through wage convergence if such exposure alters the bargaining positions of employers or workers. Inclusion of the export and import variables in the estimating equation is also important to avoid potential bias arising from exclusion of separate terms that enter into an interaction variable.

${ }^{4}$ The term $-\theta \mu_{t-1}$ is dropped from the estimating equation as we lack data relating to the period prior to our sample period, which may result in bias to the estimated coefficients of the terms multiplying $\omega_{t-1}$ as this term is by definition related to $\mu_{t-1}$. The estimated coefficient of $\Delta q_{t}$ may also be affected if there is serial correlation in the rate of growth of output. Further empirical work is planned to explore the extent of possible bias as more data become available.

${ }^{5}$ In the literature on cross-country income convergence a distinction is made between estimation of conditional convergence and unconditional convergence, which has no controls for influences on income per capita but not directly part of the convergence process.
} 
forty major economies in the world ${ }^{6}$. From the Socio Economic Accounts of the World Input-Output Database, for each two-digit NACE industry in each country, we obtain data on labour compensation, shares of high-skill, medium-skill and low-skill labour compensation in total labour compensation, total hours worked by persons engaged, shares of hours worked by high-skill, medium-skill and lowskill persons engaged in total hours, gross output, and price levels of gross output.

To calculate hourly wage rates of workers of different skill levels, we first calculate labour compensation and hours worked of each skill level. We then divide labour compensation by hours worked of each skill level to obtain hourly wage rate of workers of each skill level. The calculated wage rates based on data from WIOD are denoted in national currencies. We convert wage rates into U.S. Dollar term using the official exchange rate between various national currencies and the U.S. Dollar on an annual basis. The world average wage rate of each skill level in a two-digit NACE industry across all countries in the sample is proxied by the arithmetic average of the wage rates of a skill level in the same two-digit NACE industry across countries. We then divide the wage rate of this industry in a specific country by the world average wage in this industry to obtain the relative wage with respect to world average. The changes of the relative wages for the three skill levels from 1995 to 2008 are calculated as the difference of the natural logarithm of the relative wage in 1995 and that in 2008. The initial relative wage takes the value of the relative wage in 1995.

We also use the Input-Output Tables in WIOD to calculate the ratio of exports to domestic production and the ratio of imports to domestic sales (domestic production plus imports) for each industry of a country. The values of the ratios in 1995 are adopted as the initial values of the ratios. The growth of real gross output in a specific industry of a country is calculated as the change of the natural logarithm of the real gross output from 1995 to 2008 . We obtain real gross output by deflating gross output in current national price by price level of gross output.

Patterns for country-average hourly wage rates of three skill levels are shown in Table 1. The table shows that numerical range of wage rates for high-skill workers across countries expands from 1995 to 2008 by more than those of low- or medium-skill workers, but in relative terms the range contracts for all three skill groups with the largest relative contraction in the low-skill group. The country-average hourly wage rate of high-skill workers in 1995 ranges from 0.5 USD in China to 46.9 USD in Belgium (more than 90 to one), while in 2008 the range is 2.1 USD in India to 68.8 USD in Luxembourg (less than 35 to one); the country-average hourly wage rate of medium-skill workers in 1995 ranges from 0.3 USD in India to 33.5 USD in Luxembourg (more than 110 to one), while in 2008 the range is 0.7 USD in India to 44.4 in Denmark (less than 65 to one); the country-average hourly wage rate of low-skill workers in 1995 ranges from 0.1 USD in India to 27.1 USD in Belgium (more than 900 to one), while in 2008 the range is 0.3 USD in India to 38.1 USD in Belgium (less than 130 to one).

Table 1. Average hourly wage rates of low-skill, medium-skill and high-skill workers in forty economies, 1995 and 2008.

\begin{tabular}{|c|c|c|c|c|c|c|}
\hline & \multicolumn{2}{|c|}{$\begin{array}{c}\text { low-skill } \\
\text { hourly wage rate } \\
\text { (current US dollar) }\end{array}$} & \multicolumn{2}{c|}{$\begin{array}{c}\text { medium-skill } \\
\text { hourly wage rate } \\
\text { (current US dollar) }\end{array}$} & \multicolumn{2}{c|}{$\begin{array}{c}\text { high-skill } \\
\text { hourly wage rate } \\
\text { (current US dollar) }\end{array}$} \\
\cline { 2 - 7 } & $\mathbf{1 9 9 5}$ & $\mathbf{2 0 0 8}$ & $\mathbf{1 9 9 5}$ & $\mathbf{2 0 0 8}$ & $\mathbf{1 9 9 5}$ & $\mathbf{2 0 0 8}$ \\
\hline Belgium & 27.1 & 38.1 & 29.7 & 43.9 & 46.9 & 65.8 \\
Luxembourg & 24.8 & 32.2 & 33.5 & 43.7 & 37.3 & 68.8
\end{tabular}

\footnotetext{
${ }^{6}$ WIOD contains data covering the period 1995 to 2011 . However, the data for labour compensation are available until 2009. We drop the data for 2009 because of the significant deviation from long run trend during the Global Financial Crisis (GFC). NACE is the abbreviation for statistical classification of economic activities in the European Community.
} 


\begin{tabular}{|c|c|c|c|c|c|c|}
\hline Denmark & 20.3 & 34.4 & 26.2 & 44.4 & 32.1 & 53.7 \\
\hline Netherlands & 19.9 & 30.9 & 24.0 & 38.0 & 32.7 & 55.6 \\
\hline France & 19.5 & 32.4 & 22.7 & 36.4 & 40.7 & 56.2 \\
\hline Japan & 19.3 & 17.8 & 21.9 & 20.3 & 37.5 & 33.3 \\
\hline Finland & 19.0 & 30.6 & 18.8 & 30.1 & 25.7 & 46.1 \\
\hline Sweden & 18.2 & 33.1 & 20.2 & 34.8 & 27.5 & 45.1 \\
\hline Germany & 17.0 & 21.2 & 25.0 & 31.9 & 40.1 & 54.1 \\
\hline Austria & 15.8 & 20.0 & 24.2 & 33.2 & 41.5 & 55.6 \\
\hline Italy & 14.9 & 24.2 & 16.6 & 30.1 & 29.9 & 42.8 \\
\hline United Kingdom & 12.5 & 25.6 & 14.7 & 29.0 & 22.2 & 45.4 \\
\hline Ireland & 12.4 & 27.1 & 14.2 & 31.6 & 19.8 & 49.5 \\
\hline Spain & 11.8 & 20.6 & 15.5 & 21.7 & 25.2 & 36.2 \\
\hline Australia & 11.2 & 20.1 & 14.9 & 26.0 & 28.8 & 55.8 \\
\hline United States & 11.1 & 16.0 & 15.8 & 24.8 & 26.8 & 46.9 \\
\hline Canada & 9.5 & 17.0 & 12.6 & 24.2 & 17.2 & 35.3 \\
\hline Cyprus & 6.5 & 13.3 & 8.3 & 16.7 & 14.3 & 28.7 \\
\hline Portugal & 5.9 & 11.4 & 9.4 & 16.4 & 18.4 & 31.6 \\
\hline Taiwan & 5.9 & 7.2 & 8.0 & 8.9 & 12.7 & 13.2 \\
\hline Slovenia & 5.9 & 12.0 & 8.1 & 16.0 & 16.2 & 30.2 \\
\hline Malta & 5.7 & 11.9 & 7.4 & 15.9 & 12.6 & 31.0 \\
\hline Greece & 5.6 & 13.7 & 6.1 & 15.8 & 12.2 & 27.5 \\
\hline Republic of Korea & 5.4 & 7.3 & 6.6 & 8.9 & 10.8 & 14.2 \\
\hline Poland & 3.8 & 6.2 & 4.0 & 8.0 & 6.8 & 14.8 \\
\hline Lithuania & 2.5 & 24.4 & 3.3 & 23.1 & 6.0 & 37.9 \\
\hline Hungary & 2.1 & 5.7 & 2.8 & 7.8 & 5.7 & 18.5 \\
\hline Brazil & 1.5 & 2.8 & 2.5 & 3.6 & 5.9 & 8.6 \\
\hline Czech Republic & 1.4 & 8.3 & 1.9 & 10.1 & 3.7 & 19.0 \\
\hline Turkey & 1.3 & 4.6 & 2.2 & 6.4 & 4.5 & 12.0 \\
\hline Slovakia & 1.2 & 5.9 & 1.6 & 7.2 & 2.5 & 12.5 \\
\hline Romania & 1.1 & 6.0 & 1.5 & 7.3 & 2.2 & 12.0 \\
\hline Estonia & 1.1 & 8.9 & 1.4 & 9.2 & 2.5 & 13.6 \\
\hline Bulgaria & 1.0 & 2.8 & 1.2 & 4.0 & 1.8 & 7.0 \\
\hline Latvia & 0.9 & 5.7 & 1.0 & 6.1 & 1.7 & 12.5 \\
\hline Russia & 0.8 & 3.3 & 1.1 & 4.8 & 2.5 & 11.0 \\
\hline Indonesia & 0.6 & 1.0 & 2.1 & 2.0 & 4.8 & 6.8 \\
\hline Mexico & 0.6 & 1.0 & 2.3 & 4.3 & 3.5 & 7.3 \\
\hline China & 0.3 & 1.0 & 0.4 & 1.5 & 0.5 & 2.6 \\
\hline India & 0.1 & 0.3 & 0.3 & 0.7 & 0.8 & 2.1 \\
\hline
\end{tabular}

Source: authors' own calculation based on data from the World Input Output Database (WIOD) Note: Countries are ordered by the ranking of low-skill wage rate in 1995 from highest to lowest. The ranks of countries by medium-skill or by high-skill wage rate are in general similar to the rank by lowskill wage rate. Country-average hourly wage rates are calculated by dividing labour compensation of each skill level by hours worked of each skill level in "Total Industries" in a country.

Table 1 shows the range of country-average wage declines in relative terms between 1995 and 2008 for each skill level. However, it is unclear whether this indicates general convergence of wages of workers with same skill level and, also, what role trade activities play in the dynamics of 
wage. Therefore, we conduct regressions below to examine whether wage rates of workers with the same skill level in the same industry across countries converge over time. By using a countryindustry panel, the identification of a particular type of worker is more precise as only those workers of a given skill level working in a specific industry are regarded as one type of worker. Workers may differ in their skills and knowledge stock not only due to differing levels of education but also due to their industry-specific knowhow accumulated due to their working in a specific industry. The industry knowhow may not be easily transferable across industries and therefore it is natural to categorise workers with the same skill level in the same industry to be one type of workers.

In the regression analysis using the country-industry panel, we can also examine how trade activities influence wage dynamics. As seen in Table 2, industries vary substantially in the degree of openness to trade and there is much variation across countries within each industry (aside from the service industries). It is therefore important to assess how this difference in trade openness impacts on wage dynamics within an industry across countries. Furthermore, as discussed above, domestic wages in any period are subject to domestic influences on the demand or supply for labour and in particular the demand for labour is closely related to the level of production. In Table 2, it is found that the mean growth of gross output over the sample period varied across industries, ranging from $-34 \%$ to $116 \%$, while the standard deviation of output growth rates across countries is substantial in all industries, ranging from 0.19 to 1.54 .

Table 2. Mean and standard deviation of initial export and import shares and growth of gross output over the sample period within a certain industry across countries

\begin{tabular}{|c|c|c|c|c|c|c|}
\hline \multirow{2}{*}{ Industry } & \multicolumn{2}{|c|}{ Export share } & \multicolumn{2}{c|}{ Import share } & \multicolumn{2}{c|}{$\begin{array}{c}\text { Growth of } \\
\text { output }\end{array}$} \\
\cline { 2 - 7 } & Mean & S.d. & Mean & S.d. & Mean & S.d. \\
\hline Water Transport & 0.61 & 0.33 & 0.38 & 0.35 & 0.26 & 0.39 \\
\hline Textiles and Textile Products & 0.46 & 0.26 & 0.45 & 0.27 & -0.05 & 0.59 \\
\hline Leather and Footwear & 0.46 & 0.27 & 0.5 & 0.32 & -0.34 & 0.76 \\
\hline Electrical and Optical Equipment & 0.46 & 0.34 & 0.58 & 0.21 & 0.36 & 0.66 \\
\hline Transport Equipment & 0.44 & 0.31 & 0.53 & 0.29 & 0.46 & 0.45 \\
\hline Chemicals and Chemical Products & 0.43 & 0.27 & 0.51 & 0.24 & 0.05 & 1.54 \\
\hline Machinery, Nec & 0.42 & 0.23 & 0.54 & 0.22 & 0.58 & 0.44 \\
\hline Air Transport & 0.42 & 0.29 & 0.38 & 0.27 & 0.73 & 0.65 \\
\hline Manufacturing, Nec; Recycling & 0.36 & 0.24 & 0.35 & 0.22 & 0.52 & 0.41 \\
\hline Rubber and Plastics & 0.35 & 0.24 & 0.38 & 0.24 & 0.52 & 0.52 \\
\hline Basic Metals and Fabricated Metal & 0.32 & 0.21 & 0.36 & 0.2 & 0.65 & 0.48 \\
\hline Wood and Products of Wood and Cork & 0.27 & 0.20 & 0.23 & 0.21 & 1.01 & 0.77 \\
\hline $\begin{array}{c}\text { Other Supporting and Auxiliary Transport } \\
\text { Activities; Activities of Travel Agencies }\end{array}$ & 0.26 & 0.25 & 0.21 & 0.09 & 0.85 & 0.7 \\
\hline Pulp, Paper, Paper, Printing and Publishing & 0.23 & 0.2 & 0.27 & 0.17 & 0.56 & 0.6 \\
\hline Other Non-Metallic Mineral & 0.22 & 0.15 & 0.21 & 0.14 & 0.5 & 0.57 \\
\hline Food, Beverages and Tobacco & 0.20 & 0.18 & 0.2 & 0.15 & 0.46 & 0.39 \\
\hline
\end{tabular}




\begin{tabular}{|c|c|c|c|c|c|c|}
\hline Mining and Quarrying & 0.19 & 0.28 & 0.49 & 0.24 & 0.59 & 0.4 \\
\hline Inland Transport & 0.14 & 0.13 & 0.12 & 0.12 & 0.64 & 0.36 \\
\hline $\begin{array}{c}\text { Renting of M\&Eq and Other Business } \\
\text { Activities }\end{array}$ & 0.13 & 0.11 & 0.17 & 0.14 & 0.56 & 0.3 \\
\hline Agriculture, Hunting, Forestry and Fishing & 0.13 & 0.11 & 0.13 & 0.12 & 0.43 & 0.38 \\
\hline $\begin{array}{c}\text { Wholesale Trade and Commission Trade, } \\
\text { Except of Motor Vehicles and Motorcycles }\end{array}$ & 0.09 & 0.09 & 0.07 & 0.07 & 0.5 & 0.35 \\
\hline Post and Telecommunications & 0.08 & 0.09 & 0.09 & 0.06 & 0.41 & 0.8 \\
\hline Financial Intermediation & 0.08 & 0.14 & 0.09 & 0.11 & 0.7 & 0.79 \\
\hline Hotels and Restaurants & 0.07 & 0.12 & 0.07 & 0.1 & 0.66 & 0.37 \\
\hline $\begin{array}{c}\text { Other Community, Social and Personal } \\
\text { Services }\end{array}$ & 0.06 & 0.09 & 0.07 & 0.09 & 1.16 & 0.54 \\
\hline $\begin{array}{c}\text { Retail Trade, Except of Motor Vehicles and } \\
\text { Motorcycles; Repair of Household Goods }\end{array}$ & 0.05 & 0.08 & 0.02 & 0.02 & 0.73 & 0.5 \\
\hline $\begin{array}{c}\text { Sale, Maintenance and Repair of Motor } \\
\text { Vehicles and Motorcycles; Retail Sale of } \\
\text { Fuel }\end{array}$ & 0.04 & 0.06 & 0.06 & 0.22 & 0.49 & 0.32 \\
\hline $\begin{array}{c}\text { Electricity, Gas and Water Supply } \\
\text { Construction }\end{array}$ & 0.03 & 0.04 & 0.03 & 0.07 & 0.82 & 0.39 \\
\hline Eeal Estate Activities & 0.01 & 0.01 & 0.01 & 0.01 & 0.32 & 0.32 \\
\hline $\begin{array}{c}\text { Social Security } \\
\text { Education }\end{array}$ & 0.01 & 0.01 & 0.02 & 0.02 & 0.42 & 0.34 \\
\hline $\begin{array}{c}\text { Public Admin and Defence; Compulsory } \\
\text { Coke, Refined Petroleum and Nuclear Fuel }\end{array}$ & 0.00 & 1.55 & 0.34 & 0.28 & 0.17 & 0.19 \\
\hline $\begin{array}{c}\text { Hivate Households with Employed Persons } \\
\text { Pand Social Work }\end{array}$ & 0.01 & 0.03 & 0.35 & 0.48 & 0.45 & 0.5 \\
\hline
\end{tabular}

Source: Same as for Table 1.

Note: The industries are ordered based on the ranking of the initial mean of export share from highest to lowest.

The estimation is an ordinary least squares on a cross-section panel of countries and industries, with each observation of the dependent variable being the difference in the logarithm of the relative wage rate over the 14 year period from 1995 to 2008 for a particular country-industry pair. The initial relative wage rate as well as the export and import intensity variables are measured as levels in the first year of the data, 1995. Disturbances affecting relative wage rate growth are captured through the growth of real gross output and the initial trade exposure measures as the export share and import share in 1995. The estimating program is Stata version 14.1. The main findings for the period 1995-2008 are presented in Tables 3-5 below. 
Table 3. Unconditional convergence of growth of relative wages for low-skill, medium-skill and high-skill workers respectively at a constant rate of convergence, $1995-2008^{7}$

\begin{tabular}{|c|c|c|c|}
\hline Dependent variable: & $\begin{array}{c}\text { growth of relative } \\
\text { wage of low-skill } \\
\text { workers }\end{array}$ & $\begin{array}{c}\text { growth of relative } \\
\text { wage of medium-skill } \\
\text { workers }\end{array}$ & $\begin{array}{c}\text { growth of relative } \\
\text { wage of high-skill } \\
\text { workers }\end{array}$ \\
\hline$\omega_{t-1}$ & $-0.26^{* * *}(0.031)$ & $-0.26^{* * *}(0.030)$ & $-0.31^{* * *}(0.010)$ \\
\hline$\gamma_{0}$ & $0.19^{* * *}(0.017)$ & $0.18^{* * *}(0.016)$ & $0.025^{*}(0.066)$ \\
\hline Number of observations & 1,380 & 1,376 & 1,379 \\
\hline$R$-squared & 0.047 & 0.05 & 0.39 \\
\hline
\end{tabular}

In Table 3, we present the results for the initial wage as the only independent variable (no interaction or output growth variables). This regression allows the estimation of a constant rate of unconditional convergence across countries. The coefficient of the initial relative wage is negative and highly statistically significant for all skill groups, providing strong evidence of convergence. The estimated coefficients suggest an annual rate of convergence of about $2 \%$ per annum. ${ }^{8}$ The estimated coefficient of the initial relative wage is largest in magnitude for high-skill workers, suggesting convergence is strongest for workers in this group.

Table 4 shows the estimation results of a regression including both the initial relative wage and the interaction variables but not the output growth variable. This gives estimates for unconditional convergence at a rate that varies with trade intensity. ${ }^{9}$ The negative coefficients of the interaction of the initial relative wage with import intensity in all skill groups indicates that the rate of convergence rises with exposure to imports, while the positive coefficient of the interaction with export intensity indicates the rate of convergence falls with exports. Interestingly, the variation of the rate of convergence with the export intensity variable is opposite and almost equal in magnitude to that with the import intensity variable for all at least for the low- and medium-skill groups, which suggests it is the net trade position that affects the speed of convergence.

\footnotetext{
${ }^{7}$ The results presented in Tables 3-5 are based on regressions that do not include country or industry fixed effects. A set of country dummy variables and a set of industry dummy variables are included in another two regressions respectively. It is found that there are only minor changes in the results. In particular, all variables retain the same signs and remain statistically significant, although there are some changes in the magnitude of coefficients. Detailed results for the two sets of regressions with country and industry dummies are available from the authors.

${ }^{8} \mathrm{An}$ upper bound on the annual rate of convergence is given by dividing the negative of the estimated coefficient of the initial relative wage by $n$, where $n$ is the number of annual changes in the sample period (13 in our regressions).

${ }^{9}$ Lagged values of import and export intensity are used in the regression to avoid bias from any effect that wages changes might have on contemporaneous imports or exports.
} 
Table 4. Unconditional convergence of growth of relative wages for low-skill, medium-skill and high-skill workers respectively at rates that vary with trade intensity, 1995-2008

\begin{tabular}{|c|c|c|c|}
\hline Dependent variable: & $\begin{array}{c}\text { growth of relative } \\
\text { wage of low-skill } \\
\text { workers }\end{array}$ & $\begin{array}{c}\text { growth of relative } \\
\text { wage of medium-skill } \\
\text { workers }\end{array}$ & $\begin{array}{c}\text { growth of relative } \\
\text { wage of high-skill } \\
\text { workers }\end{array}$ \\
\hline$\omega_{t-1}$ & $-0.22^{* * *}(0.040)$ & $-0.21^{* * *}(0.039)$ & $-0.26^{* * *}(0.013)$ \\
\hline$m_{t-1} \omega_{t-1}$ & $-0.67^{* * *}(0.19)$ & $-0.69^{* * *}(0.18)$ & $-0.33^{* * *}(0.058)$ \\
\hline$x_{t-1} \omega_{t-1}$ & $0.74^{* * *}(0.21)$ & $0.73^{* * *}(0.20)$ & $0.16^{* *}(0.064)$ \\
\hline$\gamma_{0}$ & $0.18^{* * *}(0.017)$ & $0.17^{* * *}(0.016)$ & $0.025^{*}(0.013)$ \\
\hline Number of observations & 1,326 & 1,322 & 1,326 \\
\hline$R$-squared & 0.043 & 0.04 & 0.39 \\
\hline
\end{tabular}

As with the regressions in Table 3 , the coefficient estimate of $b_{0}$ is the largest in magnitude for high-skill workers. This result suggests that wage convergence occurring in the absence of trade via mechanisms such as immigration, capital flows or technology transfer is strongest for high-skill workers. The coefficient estimate of $b_{1}$ is the smallest in magnitude for high-skill workers, suggesting a larger exposure to imports is more effective in causing low-skill and medium-skill wages to converge than high-skill wages. The coefficient estimate of $b_{2}$ is also the smallest in magnitude for high-skill workers, implying larger exposure to exports is more effective in causing high-skill worker wages to converge than low-skill and medium-skill wages. Therefore, trade, whether in the form of import or export, has a greater impact on the dynamics of wages of low-skill and medium-skill workers than that of high-skill workers.

Table 5 presents the results of regressions based on Equation 11, which include the rate of growth of real gross output and levels of import and exports intensity as an additional explanatory variables. The coefficient estimates of $\gamma_{1}$ are each positive and highly statistically significant, providing evidence that domestic production growth disturbs the convergence process for wages. The coefficient estimate of $\gamma_{1}$ is the smallest in magnitude for high-skill workers, which suggests low-skill and medium-skill wages are more subject to the influence of the demand for labour than are high-skill wages. The coefficient estimates for $\gamma_{2}$ show that exposure to imports has a positive impact on wage growth for low-skill and medium-skill workers, but no significant impact on wage growth for high-skill workers. In contrast, the coefficient estimates for $\gamma_{3}$ show that exposure to exports has a positive impact on wage growth for high-skill workers, but no significant impact on wage growth for low-skill or medium-skill workers.

Controlling for disturbances to unconditional convergence through the additional variables in Table 5 doesn't have much effect on the other estimated coefficients as compared to the corresponding estimate in Table 4. We still have strong evidence of convergence through the negative and highly significant coefficient estimates of $b_{0}$ in all skill groups, but the convergence is conditional on the absence of output growth or exposure to trade that differs from the mean values in that industry across the sample of countries. 
Table 5. Conditional convergence of growth of relative wages for low-skill, medium-skill and highskill workers respectively, 1995-2008

\begin{tabular}{|c|c|c|c|}
\hline Dependent variable: & $\begin{array}{c}\text { growth of relative } \\
\text { wage of low-skill } \\
\text { workers }\end{array}$ & $\begin{array}{c}\text { growth of relative } \\
\text { wage of medium-skill } \\
\text { workers }\end{array}$ & $\begin{array}{c}\text { growth of relative } \\
\text { wage of high-skill } \\
\text { workers }\end{array}$ \\
\hline$\omega_{t-1}$ & $-0.25^{* * *}(0.040)$ & $-0.23^{* * *}(0.038)$ & $-0.26^{* * *}(0.014)$ \\
\hline$m_{t-1}$ & $0.25^{* *}(0.10)$ & $0.23^{* *}(0.092)$ & $0.036(0.085)$ \\
\hline$x_{t-1}$ & $-0.068(0.10)$ & $-0.10(0.093)$ & $0.19^{* *}(0.085)$ \\
\hline$m_{t-1} \omega_{t-1}$ & $-0.54^{* * *}(0.19)$ & $-0.58^{* * *}(0.18)$ & $-0.31^{* * *}(0.066)$ \\
\hline$x_{t-1} \omega_{t-1}$ & $0.65^{* * *}(0.21)$ & $0.66^{* * *}(0.20)$ & $0.20^{* * *}(0.064)$ \\
\hline$\Delta$ output & $0.27^{* * *}(0.027)$ & $0.26^{* * *}(0.025)$ & $0.078^{* * *}(0.022)$ \\
\hline$\gamma_{0}$ & $0.00021(0.994)$ & $0.0030(0.024)$ & $-0.058^{* * *}(0.020)$ \\
\hline Number of observations & 1,326 & 1,322 & 1,326 \\
\hline R-squared & 0.12 & 0.12 & 0.40 \\
\hline
\end{tabular}

\section{Conclusions}

We find strong evidence of convergence across countries in the wage rates of workers of the same skill group within the same industry classification. Average rates of convergence are very similar for low-skill and medium-skill workers while slightly higher for high-skill workers. Convergence is generally slow, our estimates suggest about $2 \%$ per annum even for the high-skill group, and the initial wage differentials are large so there is no indication of wage equalisation in the near or intermediate future. Also, output growth rates across countries are found to substantially impact on relative wage rates independently of the convergence process, which means differential rates of output growth can offset as well as reinforce convergence. There are also direct impacts of exposure to trade on wage growth further complicating the convergence process.

Our estimates suggest the speed of convergence rises substantially with exposure to imports but falls substantially with the intensity of exporting, with the estimated coefficients of export and import intensity approximately equal in magnitude for low- and medium-skill workers. Seemingly, for workers in the low- and medium-skill groups wage rates in countries with net export positions have greater independence from the levelling impact of globalisation, while countries with net import positions are most impacted by this levelling impact. In this sense, the net exporters can be considered to be wage leaders for low- and medium skill workers in a world economy moving towards full integration.

Interestingly, the effect of trade in goods on the speed of convergence, both imports and exports, is less strong for workers in the high-skill group than for low- and medium skill workers. Also, the magnitude of the coefficient on import intensity interacted with the initial wage rate is higher than the corresponding coefficient for export intensity for workers in this group, so greater exposure to imports and exports of goods increases convergence even with balanced trade. With or without accounting for balanced trade, the average rate of convergence is higher than for low-skill and medium-skill workers, which suggests other mechanisms of integration, such as immigration, are strongest for high-skill workers.

Our purpose in this paper is to examine wage convergence as a global process. Our results cover a wide range of countries and industries, which we implicitly assume are all subject to the same convergence relationship. Further results reported in the Appendix suggest manufacturing industries have stronger trade effects on convergence than do service industries. Also, the effect of 
trade on convergence seems slower within already integrated markets, specifically the sub-sample of countries that are members of the European Union. Future work can seek to establish the differing patterns of the convergence process within narrower groups of countries or industries. Also, future work can seek to establish whether convergence is nonlinear, with countries further from the mean having faster or slower convergence, or is asymmetric, with countries with wages above and below the average level having different convergence patterns.

\section{$\underline{\text { References }}$}

Baldwin, Richard and Frédéric Robert-Nicoud, (2014), 'Trade-in-goods and trade-in-tasks: An integrating framework', Journal of International Economics, 92: 51-62.

Haskel, Jonathan, Robert Z. Lawrence, Edward E. Learner and Matthew J. Slaughter (2012), 'Globalization and U.S. wages: Modifying classic theory to explain recent facts', Journal of Economic Perspectives, 26(2): 119-13.

Mora, Toni, Jordi López-Tamayo and Jordi Suriñach (2005), 'Are wages and productivity converging simultaneously in Euro-area countries? Applied Economics, 37: 2001-2008.

O’Rourke, Kevin H. and Jeffrey G. Williamson (1999), Globalisation and History, Cambridge, MA, MIT Press.

Parteka, Aleksandra and Joanna Wolszczak-Derlacz (2015), 'Integrated sectors - diversified earnings: the (missing) impact of offshoring on wages and wage convergence in the EU27', Journal of Economic Inequality, 13: 325-350.

Ramskogler, Paul (2012), 'Is there a European wage leader? Wage spillovers in the European Monetary Union', Cambridge Journal of Economics, 36: 941-962.

Stolper, W. and P. A. Samuelson (1941), 'Protection and real wages', Review of Economic Studies, 9(1): 58-73.

Traxler, F., B. Brandl, V. Glassner and A. Ludvig (2008), 'Can cross-border bargaining coordination work? Analytical reflections and evidence from the metal industry in Germany and Austria', European Journal of Industrial Relations, 14(2): 217-37. 
Appendix:

Table A.1. Fixed-effects model, industry-dummies, unconditional convergence of growth of relative wages for low-skill, medium-skill and high-skill workers respectively at a constant rate of convergence, 1995-2008

\begin{tabular}{|c|c|c|c|}
\hline Dependent variable: & $\begin{array}{c}\text { growth of relative } \\
\text { wage of low-skill } \\
\text { workers }\end{array}$ & $\begin{array}{c}\text { growth of relative } \\
\text { wage of medium-skill } \\
\text { workers }\end{array}$ & $\begin{array}{c}\text { growth of relative } \\
\text { wage of high-skill } \\
\text { workers }\end{array}$ \\
\hline$\omega_{t-1}$ & $-0.39 * * *(0.037)$ & $-0.38^{* * *}(0.036)$ & $-0.31^{* * *}(0.010)$ \\
\hline$\gamma_{0}$ & $0.15(0.099)$ & $0.14(0.092)$ & $0.019(0.074)$ \\
\hline Number of observations & 1,380 & 1,376 & 1,379 \\
\hline R-squared & 0.085 & 0.05 & 0.40 \\
\hline
\end{tabular}

Table A.2. Fixed-effects model, industry-dummies, unconditional convergence of growth of relative wages for low-skill, medium-skill and high-skill workers respectively at rates that vary with trade intensity, 1995-2008

\begin{tabular}{|c|c|c|c|}
\hline Dependent variable: & $\begin{array}{c}\text { growth of relative } \\
\text { wage of low-skill } \\
\text { workers }\end{array}$ & $\begin{array}{c}\text { growth of relative } \\
\text { wage of medium-skill } \\
\text { workers }\end{array}$ & $\begin{array}{c}\text { growth of relative } \\
\text { wage of high-skill } \\
\text { workers }\end{array}$ \\
\hline$\omega_{t-1}$ & $-0.33^{* * *}(0.047)$ & $-0.31^{* * *}(0.045)$ & $-0.25^{* * *}(0.013)$ \\
\hline$m_{t-1} \omega_{t-1}$ & $-0.61^{* * *}(0.20)$ & $-0.62^{* * *}(0.18)$ & $-0.33^{* * *}(0.060)$ \\
\hline$x_{t-1} \omega_{t-1}$ & $0.63^{* * *}(0.22)$ & $0.62^{* * *}(0.21)$ & $0.14^{* *}(0.067)$ \\
\hline$\gamma_{0}$ & $0.14(0.099)$ & $0.12(0.091)$ & $0.022(0.073)$ \\
\hline Number of observations & 1,326 & 1,322 & 1,326 \\
\hline R-squared & 0.070 & 0.073 & 0.39 \\
\hline
\end{tabular}

Table A.3. Fixed-effects model, industry-dummies, conditional convergence of growth of relative wages for low-skill, medium-skill and high-skill workers respectively, 1995-2008

\begin{tabular}{|c|c|c|c|}
\hline Dependent variable: & $\begin{array}{c}\text { growth of relative } \\
\text { wage of low-skill } \\
\text { workers }\end{array}$ & $\begin{array}{c}\text { growth of relative } \\
\text { wage of medium-skill } \\
\text { workers }\end{array}$ & $\begin{array}{c}\text { growth of relative } \\
\text { wage of high-skill } \\
\text { workers }\end{array}$ \\
\hline$\omega_{t-1}$ & $-0.31^{* * *}(0.045)$ & $-0.29^{* * *}(0.043)$ & $-0.26^{* * *}(0.014)$ \\
\hline$m_{t-1}$ & $0.42^{* * *}(0.12)$ & $0.38^{* * *}(0.11)$ & $0.32^{* * *}(0.097)$ \\
\hline$x_{t-1}$ & $0.0094(0.11)$ & $-0.022(0.10)$ & $0.35^{* * *}(0.092)$ \\
\hline$m_{t-1} \omega_{t-1}$ & $-0.42^{* *}(0.19)$ & $-0.45^{* *}(0.18)$ & $-0.29^{* * *}(0.066)$ \\
\hline$x_{t-1} \omega_{t-1}$ & $0.56^{* * *}(0.21)$ & $0.59^{* * *}(0.20)$ & $0.17^{* *}(0.071)$ \\
\hline$\Delta$ output & $0.31^{* *}(0.030)$ & $0.30^{* * *}(0.028)$ & $0.092^{* * *}(0.025)$ \\
\hline$\gamma_{0}$ & $-0.017(0.096)$ & $-0.016(0.088)$ & $-0.13^{*}(0.072)$ \\
\hline Number of observations & 1,326 & 1,322 & 1,326 \\
\hline R-squared & 0.16 & 0.16 & 0.44 \\
\hline
\end{tabular}


Table A.4. Fixed-effects model, country-dummies, unconditional convergence of growth of relative wages for low-skill, medium-skill and high-skill workers respectively at a constant rate of convergence, 1995-2008

\begin{tabular}{|c|c|c|c|}
\hline Dependent variable: & $\begin{array}{c}\text { growth of relative } \\
\text { wage of low-skill } \\
\text { workers }\end{array}$ & $\begin{array}{c}\text { growth of relative } \\
\text { wage of medium-skill } \\
\text { workers }\end{array}$ & $\begin{array}{c}\text { growth of relative } \\
\text { wage of high-skill } \\
\text { workers }\end{array}$ \\
\hline$\omega_{t-1}$ & $-0.26^{* * *}(0.017)$ & $-0.25^{* * *}(0.017)$ & $-0.40^{* * *}(0.020)$ \\
\hline$\gamma_{0}$ & $0.044(0.057)$ & $0.015(0.054)$ & $0.17^{* * *}(0.054)$ \\
\hline Number of observations & 1,380 & 1,376 & 1,379 \\
\hline$R$-squared & 0.75 & 0.73 & 0.73 \\
\hline
\end{tabular}

Table A.5. Fixed-effects model, country-dummies, unconditional convergence of growth of relative wages for low-skill, medium-skill and high-skill workers respectively at rates that vary with trade intensity, 1995-2008

\begin{tabular}{|c|c|c|c|}
\hline Dependent variable: & $\begin{array}{c}\text { growth of relative } \\
\text { wage of low-skill } \\
\text { workers }\end{array}$ & $\begin{array}{c}\text { growth of relative } \\
\text { wage of medium-skill } \\
\text { workers }\end{array}$ & $\begin{array}{c}\text { growth of relative } \\
\text { wage of high-skill } \\
\text { workers }\end{array}$ \\
\hline$\omega_{t-1}$ & $-0.23^{* * *}(0.021)$ & $-0.22^{* * *}(0.021)$ & $-0.37^{* * *}(0.020)$ \\
\hline$m_{t-1} \omega_{t-1}$ & $-0.43^{* * *}(0.10)$ & $-0.48^{* * *}(0.099)$ & $-0.11^{* * *}(0.041)$ \\
\hline$x_{t-1} \omega_{t-1}$ & $0.47^{* * *}(0.1)$ & $0.54^{* * *}(0.11)$ & $0.17^{* * *}(0.045)$ \\
\hline$\gamma_{0}$ & $0.044(0.054)$ & $0.013(0.052)$ & $0.17^{* * *}(0.053)$ \\
\hline Number of observations & 1,326 & 1,322 & 1,326 \\
\hline$R$-squared & 0.76 & 0.74 & 0.31 \\
\hline
\end{tabular}

Table A.6. Fixed-effects model, country-dummies, conditional convergence of growth of relative wages for low-skill, medium-skill and high-skill workers respectively, 1995-2008

\begin{tabular}{|c|c|c|c|}
\hline Dependent variable: & $\begin{array}{c}\text { growth of relative } \\
\text { wage of low-skill } \\
\text { workers }\end{array}$ & $\begin{array}{c}\text { growth of relative } \\
\text { wage of medium-skill } \\
\text { workers }\end{array}$ & $\begin{array}{c}\text { growth of relative } \\
\text { wage of high-skill } \\
\text { workers }\end{array}$ \\
\hline$\omega_{t-1}$ & $-0.24^{* * *}(0.022)$ & $-0.23^{* * *}(0.022)$ & $-0.37^{* * *}(0.020)$ \\
\hline$m_{t-1}$ & $0.096^{*}(0.055)$ & $0.078(0.053)$ & $-0.055(0.060)$ \\
\hline$x_{t-1}$ & $-0.082(0.058)$ & $-0.089^{*}(0.053)$ & $0.050(0.060)$ \\
\hline$m_{t-1} \omega_{t-1}$ & $-0.37^{* * *}(0.10)$ & $-0.43^{* * *}(0.10)$ & $-0.11^{* *}(0.047)$ \\
\hline$x_{t-1} \omega_{t-1}$ & $0.40^{* * *}(0.11)$ & $0.49^{* * *}(0.11)$ & $0.19^{* * *}(0.050)$ \\
\hline$\Delta$ output & $0.080^{* * *}(0.016)$ & $0.074^{* * *}(0.015)$ & $0.064^{* * *}(0.016)$ \\
\hline$\gamma_{0}$ & $0.015(0.054)$ & $-0.0095(0.052)$ & $0.15^{* * *}(0.053)$ \\
\hline Number of observations & 1,326 & 1,322 & 1,326 \\
\hline$R$-squared & 0.76 & 0.74 & 0.73 \\
\hline
\end{tabular}


Table A.7 Manufacturing industries, unconditional convergence of growth of relative wages for low-skill, medium-skill and high-skill workers respectively at a constant rate of convergence, 19952008

\begin{tabular}{|c|c|c|c|}
\hline Dependent variable: & $\begin{array}{c}\text { growth of relative } \\
\text { wage of low-skill } \\
\text { workers }\end{array}$ & $\begin{array}{c}\text { growth of relative } \\
\text { wage of medium-skill } \\
\text { workers }\end{array}$ & $\begin{array}{c}\text { growth of relative } \\
\text { wage of high-skill } \\
\text { workers }\end{array}$ \\
\hline$\omega_{t-1}$ & $-0.29^{* * *}(0.058)$ & $-0.28^{* * *}(0.053)$ & $-0.29^{* * *}(0.016)$ \\
\hline$\gamma_{0}$ & $0.17^{* * *}(0.027)$ & $0.15^{* * *}(0.024)$ & $0.015(0.021)$ \\
\hline Number of observations & 556 & 556 & 556 \\
\hline$R$-squared & 0.043 & 0.047 & 0.37 \\
\hline
\end{tabular}

Table A.8 Manufacturing industries, unconditional convergence of growth of relative wages for low-skill, medium-skill and high-skill workers respectively at rates that vary with trade intensity, 1995-2008

\begin{tabular}{|c|c|c|c|}
\hline Dependent variable: & $\begin{array}{c}\text { growth of relative } \\
\text { wage of low-skill } \\
\text { workers }\end{array}$ & $\begin{array}{c}\text { growth of relative } \\
\text { wage of medium-skill } \\
\text { workers }\end{array}$ & $\begin{array}{c}\text { growth of relative } \\
\text { wage of high-skill } \\
\text { workers }\end{array}$ \\
\hline$\omega_{t-1}$ & $-0.11(0.093)$ & $-0.11(0.084)$ & $-0.16^{* * *}(0.025)$ \\
\hline$m_{t-1} \omega_{t-1}$ & $-0.94^{* * *}(0.22)$ & $-0.99^{* * *}(0.19)$ & $-0.40^{* * *}(0.068)$ \\
\hline$x_{t-1} \omega_{t-1}$ & $0.68^{* *}(0.27)$ & $0.75^{* * *}(0.24)$ & $0.12(0.080)$ \\
\hline$\gamma_{0}$ & $0.044(0.029)$ & $0.24^{* * *}(0.029)$ & $0.097^{* * *}(0.027)$ \\
\hline Number of observations & 542 & 1542 & 542 \\
\hline R-squared & 0.16 & 0.18 & 0.43 \\
\hline
\end{tabular}

Table A.9 Manufacturing industries, conditional convergence of growth of relative wages for lowskill, medium-skill and high-skill workers respectively, 1995-2008

\begin{tabular}{|c|c|c|c|}
\hline Dependent variable: & $\begin{array}{c}\text { growth of relative } \\
\text { wage of low-skill } \\
\text { workers }\end{array}$ & $\begin{array}{c}\text { growth of relative } \\
\text { wage of medium-skill } \\
\text { workers }\end{array}$ & $\begin{array}{c}\text { growth of relative } \\
\text { wage of high-skill } \\
\text { workers }\end{array}$ \\
\hline$\omega_{t-1}$ & $-0.18^{*}(0.095)$ & $-0.16^{*}(0.086)$ & $-0.20^{* * *}(0.026)$ \\
\hline$m_{t-1}$ & $0.33^{* *}(0.15)$ & $0.29^{* *}(0.13)$ & $0.13(0.11)$ \\
\hline$x_{t-1}$ & $-0.061(0.14)$ & $-0.095(0.13)$ & $0.29^{* * *}(0.11)$ \\
\hline$m_{t-1} \omega_{t-1}$ & $-0.73^{* * *}(0.23)$ & $-0.81^{* * *}(0.21)$ & $-0.38^{* * *}(0.077)$ \\
\hline$x_{t-1} \omega_{t-1}$ & $0.60^{* *}(0.28)$ & $0.67^{* * *}(0.25)$ & $0.18^{* *}(0.087)$ \\
\hline$\Delta$ output & $0.27^{* * *}(0.033)$ & $0.24^{* * *}(0.029)$ & $0.085^{* * *}(0.026)$ \\
\hline$\gamma_{0}$ & $-0.064(0.049)$ & $-0.043(0.043)$ & $-0.17^{* * *}(0.037)$ \\
\hline Number of observations & 542 & 542 & 542 \\
\hline$R$-squared & 0.18 & 0.19 & 0.46 \\
\hline
\end{tabular}


Table A.10 Service industries, unconditional convergence of growth of relative wages for low-skill, medium-skill and high-skill workers respectively at a constant rate of convergence, 1995-2008

\begin{tabular}{|c|c|c|c|}
\hline Dependent variable: & $\begin{array}{c}\text { growth of relative } \\
\text { wage of low-skill } \\
\text { workers }\end{array}$ & $\begin{array}{c}\text { growth of relative } \\
\text { wage of medium-skill } \\
\text { workers }\end{array}$ & $\begin{array}{c}\text { growth of relative } \\
\text { wage of high-skill } \\
\text { workers }\end{array}$ \\
\hline$\omega_{t-1}$ & $-0.27^{* * *}(0.040)$ & $-0.28^{* * *}(0.039)$ & $-0.32^{* * *}(0.014)$ \\
\hline$\gamma_{0}$ & $0.20^{* * *}(0.024)$ & $0.19^{* * *}(0.023)$ & $0.032^{*}(0.019)$ \\
\hline Number of observations & 744 & 740 & 743 \\
\hline$R$-squared & 0.058 & 0.064 & 0.40 \\
\hline
\end{tabular}

Table A.11 Service industries, unconditional convergence of growth of relative wages for low-skill, medium-skill and high-skill workers respectively at rates that vary with trade intensity, 1995-2008

\begin{tabular}{|c|c|c|c|}
\hline Dependent variable: & $\begin{array}{c}\text { growth of relative } \\
\text { wage of low-skill } \\
\text { workers }\end{array}$ & $\begin{array}{c}\text { growth of relative } \\
\text { wage of medium-skill } \\
\text { workers }\end{array}$ & $\begin{array}{c}\text { growth of relative } \\
\text { wage of high-skill } \\
\text { workers }\end{array}$ \\
\hline$\omega_{t-1}$ & $-0.28^{* * *}(0.046)$ & $-0.27^{* * *}(0.046)$ & $-0.28^{* * *}(0.017)$ \\
\hline$m_{t-1} \omega_{t-1}$ & $0.54(0.56)$ & $0.27(0.54)$ & $-0.45^{* *}(0.18)$ \\
\hline$x_{t-1} \omega_{t-1}$ & $-0.085(0.49)$ & $0.10(0.48)$ & $0.17(0.15)$ \\
\hline$\gamma_{0}$ & $0.27^{* * *}(0.048)$ & $0.28^{* * *}(0.044)$ & $0.072^{*}(0.038)$ \\
\hline Number of observations & 706 & 702 & 1706 \\
\hline R-squared & 0.092 & 0.10 & 0.40 \\
\hline
\end{tabular}

Table A.12 Service industries, conditional convergence of growth of relative wages for low-skill, medium-skill and high-skill workers respectively, 1995-2008

\begin{tabular}{|c|c|c|c|}
\hline Dependent variable: & $\begin{array}{c}\text { growth of relative } \\
\text { wage of low-skill } \\
\text { workers }\end{array}$ & $\begin{array}{c}\text { growth of relative } \\
\text { wage of medium-skill } \\
\text { workers }\end{array}$ & $\begin{array}{c}\text { growth of relative } \\
\text { wage of high-skill } \\
\text { workers }\end{array}$ \\
\hline$\omega_{t-1}$ & $-0.28^{* * *}(0.047)$ & $-0.28^{* * *}(0.046)$ & $-0.28^{* * *}(0.017)$ \\
\hline$m_{t-1}$ & $0.17(0.24)$ & $0.16(0.22)$ & $0.17(0.20)$ \\
\hline$x_{t-1}$ & $0.096(0.20)$ & $0.047(0.19)$ & $0.04(0.16)$ \\
\hline$m_{t-1} \omega_{t-1}$ & $0.60(0.57)$ & $0.36(0.55)$ & $-0.36 *(0.19)$ \\
\hline$x_{t-1} \omega_{t-1}$ & $-0.18(0.49)$ & $0.061(0.48)$ & $0.16(0.16)$ \\
\hline$\Delta$ output & $0.26^{* * *}(0.048)$ & $0.27^{* * *}(0.045)$ & $0.060(0.038)$ \\
\hline$\gamma_{0}$ & $0.019(0.037)$ & $0.0040(0.035)$ & $-0.019(0.028)$ \\
\hline Number of observations & 706 & 702 & 706 \\
\hline R-squared & 0.098 & 0.10 & 0.40 \\
\hline
\end{tabular}


Table A.13 EU countries, unconditional convergence of growth of relative wages for low-skill, medium-skill and high-skill workers respectively at a constant rate of convergence, 1995-2008

\begin{tabular}{|c|c|c|c|}
\hline Dependent variable: & $\begin{array}{c}\text { growth of relative } \\
\text { wage of low-skill } \\
\text { workers }\end{array}$ & $\begin{array}{c}\text { growth of relative } \\
\text { wage of medium-skill } \\
\text { workers }\end{array}$ & $\begin{array}{c}\text { growth of relative } \\
\text { wage of high-skill } \\
\text { workers }\end{array}$ \\
\hline$\omega_{t-1}$ & $-0.36^{* * *}(0.045)$ & $-0.36^{* * *}(0.041)$ & $-0.44^{* * *}(0.011)$ \\
\hline$\gamma_{0}$ & $0.28^{* * *}(0.021)$ & $0.26^{* * *}(0.019)$ & $0.12^{*}(0.011)$ \\
\hline Number of observations & 934 & 934 & 934 \\
\hline$R$-squared & 0.062 & 0.076 & 0.65 \\
\hline
\end{tabular}

Table A.14 EU countries, unconditional convergence of growth of relative wages for low-skill, medium-skill and high-skill workers respectively at rates that vary with trade intensity, 1995-2008

\begin{tabular}{|c|c|c|c|}
\hline Dependent variable: & $\begin{array}{c}\text { growth of relative } \\
\text { wage of low-skill } \\
\text { workers }\end{array}$ & $\begin{array}{c}\text { growth of relative } \\
\text { wage of medium-skill } \\
\text { workers }\end{array}$ & $\begin{array}{c}\text { growth of relative } \\
\text { wage of high-skill } \\
\text { workers }\end{array}$ \\
\hline$\omega_{t-1}$ & $-0.28^{* * *}(0.064)$ & $-0.25^{* * *}(0.058)$ & $-0.42^{* * *}(0.015)$ \\
\hline$m_{t-1} \omega_{t-1}$ & $-0.46^{*}(0.24)$ & $-0.48^{* *}(0.22)$ & $-0.058(0.052)$ \\
\hline$x_{t-1} \omega_{t-1}$ & $0.44(0.27)$ & $0.41^{*}(0.25)$ & $0.11^{*}(0.057)$ \\
\hline$\gamma_{0}$ & $0.29^{* * *}(0.032)$ & $0.25^{* * *}(0.028)$ & $0.091^{* * *}(0.019)$ \\
\hline Number of observations & 883 & 883 & 883 \\
\hline R-squared & 0.12 & 0.12 & 0.65 \\
\hline
\end{tabular}

Table A.15 EU countries, conditional convergence of growth of relative wages for low-skill, medium-skill and high-skill workers respectively, 1995-2008

\begin{tabular}{|c|c|c|c|}
\hline Dependent variable: & $\begin{array}{c}\text { growth of relative } \\
\text { wage of low-skill } \\
\text { workers }\end{array}$ & $\begin{array}{c}\text { growth of relative } \\
\text { wage of medium-skill } \\
\text { workers }\end{array}$ & $\begin{array}{c}\text { growth of relative } \\
\text { wage of high-skill } \\
\text { workers }\end{array}$ \\
\hline$\omega_{t-1}$ & $-0.29^{* * *}(0.066)$ & $-0.25^{* * *}(0.059)$ & $-0.43^{* * *}(0.015)$ \\
\hline$m_{t-1}$ & $0.087(0.11)$ & $0.077(0.10)$ & $-0.15^{* *}(0.069)$ \\
\hline$x_{t-1}$ & $-0.060(0.12)$ & $-0.098(0.10)$ & $0.21^{* * *}(0.068)$ \\
\hline$m_{t-1} \omega_{t-1}$ & $-0.42^{*}(0.25)$ & $-0.45^{* *}(0.22)$ & $-0.12^{* *}(0.058)$ \\
\hline$x_{t-1} \omega_{t-1}$ & $0.42(0.27)$ & $0.38(0.25)$ & $0.18^{*}(0.062)$ \\
\hline$\Delta$ output & $0.26^{* * *}(0.048)$ & $0.25^{* * *}(0.029)$ & $0.088^{* * *}(0.019)$ \\
\hline$\gamma_{0}$ & $0.29(0.032)$ & $0.14^{* * *}(0.029)$ & $0.074^{* * *}(0.017)$ \\
\hline Number of observations & 883 & 883 & 883 \\
\hline R-squared & 0.12 & 0.12 & 0.66 \\
\hline
\end{tabular}

